Published by LPMP Imperium

Journal homepage: https:/ / ejournal.imperiuminstitute.org/ index.php/JMSAB

\title{
Pengaruh Pemasaran Digital dan Suasana Toko Terhadap Minat Beli di Kedai Kopi S
}

\author{
Khalifachri Albi \\ Manajemen, Sekolah Tinggi Ilmu Ekonomi Indonesia Sains dan \\ Manajemen (STIE ISM)
}

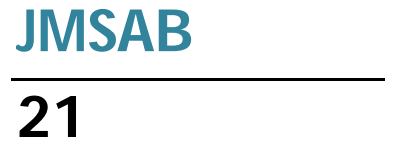

Paper type

Research paper

$\begin{array}{lr}\text { Keywords: } & \text { digital } \\ \text { marketing, } & \text { store } \\ \text { atmosphere, } & \text { purchase } \\ \text { decision } & \end{array}$

Received: 6 Dec 2019

Revised: 14 Jan 2020

Accepted: 20 Jan 2020

Online: 22 Jan 2020

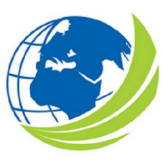

Jurnal Manajemen Strategi dan Aplikasi Bisnis, Vol 3, No.1, Januari 2020, pp. 21 - 30 eISSN 2655-237X
Pedoman Sitasi: Albi, K (2020). Pengaruh Pemasaran Digital dan Suasana Toko Terhadap Minat Beli di Kedai Kopi S. Jurnal Manajemen Strategi dan $\begin{array}{lllll}\text { Aplikasi Bisnis, } 3(1), & 21 & \text { - } & 30 . & \text { DOI: }\end{array}$ https:/ / doi.org/ 10.36407/jmsab.v2i1.116 


\section{PENDAHULUAN}

Teknik pemasaran tradisional sekarang ini telah berkembang untuk dan menggabungkan teknik pemasaran digital baru, di mana pelanggan potensial dianggap sebagai pengguna. Pengguna ini adalah orang yang membeli atau menggunakan produk dan layanan di Internet, dan yang juga menjadi penuntut dengan menghasilkan konten yang berinteraksi dengan merek melalui Internet (Diez-Martin, Blanco-Gonzalez, \& Prado-Roman, 2019). Globalisasi telah menyebabkan perubahan dimana informasi dan pengetahuan memainkan peran penting. Model bisnis baru sedang terlihat di mana konsep tradisional bisnis, pelanggan, perpajakan, dan mata uang berubah. Dari sudut pandang ini, dapat dilihat bahwa ekonomi harus menyesuaikan metodenya untuk memenuhi kebutuhan individu. Teknik baru telah berkembang untuk apa yang oleh beberapa penulis dianggap sebagai ekonomi baru atau ekonomi informasi. Jaringan informasi global mengubah dunia, menyebabkan perubahan berbagai bidang aktivitas manusia, seperti daya saing, pekerjaan, dan kualitas hidup.

Perkembangan teknologi telah mengarahkan para praktisi merubah strategi saluran pemasaran mereka berbasis online, atau dikenal dengan digital marketing. Digital marketing merupakan kegiatan yang dijalankan oleh perusahasan untuk meningkatkan pengenalan produk melalui media elektronik / media digital sehingga dapat menjangkau konsumen secara luas, tanpa batatsan wilayah geografis. Pergeseran gaya hidup dan perilaku konsumen yang sekarang lebih banyak mengadopsi teknologi digital secara fundamental mengubah perilaku konsumen dalam melakukan pembelian. Dengan demikian, penting bagi pemasar untuk memahami pengaruh pemasaran digital terhadap perilaku konsumen.

Pemasaran digital dapat didefinisikan sebagai metode di mana produk dan layanan dipromosikan melalui saluran distribusi digital. Pemasaran digital juga disebut sebagai pemasaran elektronik dan mencakup iklan digital atau online, yang mengirimkan pesan pemasaran kepada pelanggan. Menurut Okazaki, Katsukura, dan Nishiyama (2007), menjangkau konsumen melalui media digital adalah salah satu bidang penelitian pemasaran yang akan datang (Joshi, 2013). Lanjut, Edelman (dalam Joshi, 2013) menjelaskan bahwa metode lama yang dijalankan pemasar tidak terlalu efektif dalam meningkatkan penjualan. Saluran penjualan dan komunikasi terbaru sebagian besar bersifat elektronik. Internet telah menyediakan platform bagi konsumen dan pemasar untuk memiliki lebih banyak interaksi dan telah membuat penyesuaian layanan. Perusahaan dapat mengirim pesan khusus yang meningkatkan keterlibatan pelanggan dalam berbagai kegiatan seperti produksi dan strategi pemasaran sehingga perusahaan dapat menyesuaikan aktivitas bisnisnya berdasarkan kebutuhan konsumen. Akibatnya, dalam skenario pemasaran saat ini, pemasaran digital secara bertahap lebih disukai daripada pemasaran tradisional. Sangat sulit bagi para pemasar untuk memasarkan produk di era digital ini tanpa mempertimbangkan pentingnya teknologi digital yang canggih. Pemasaran digital juga sangat bermanfaat bagi perusahaan karena pemasaran digital adalah iklan yang hemat biaya dan telepon pintar adalah saluran yang paling jelas bagi pengiklan, yang membuat evolusi dalam pemasaran digital (Ahuja 2015).

Meskipun isu pemasaran digital sudah banyak menarik perhatian, studi mengenai isu ini masih relative terbatas. Penelitian yang paling relevan adalah dari Pauwels, Aksehirli, dan Lackman (2016); Järvinen dan Karjaluoto (2015); Jayaram dan Manrai (2015); Khan dan Islam (2017); dan López García et al. (2019). Pauwels et al. (2016) menguji hubungan elektronik WOM pada konten promosi online dan offline. Jayaram dan Manrai (2015) menganalisis perilaku pengguna dengan promosi di media sosial, kampanye digital dan aplikasi seluler, dan algoritma matematika diusulkan untuk menganalisis efektivitas pencarian pemasaran (pemasaran konten). Khan dan Islam (2017) dalam penelitiannya menemukan bahwa dimensi digital marketing yaitu nilai tambah memiliki peringkat teratas dalam hal peningkatan loyalitas pelanggan di Bangladesh. López García et al. (2019) menemukan bahwa tindakan paling penting untuk mencapai loyalitas pengguna adalah dengan pemasaran digital. 
Penelitian ini bertujuan untuk menguji pengaruh digital marketing terhadap minat beli konsumen. Berbeda dengan penelitian sebelumnya (Khan dan Islam, 2017; López García et al., 2019), studi ini menambahkan satu variabel yaitu suasana toko sebagai prediktor minat konsumen, khususnya pada sektor makanan dan minuman. Manfaat dari studi ini, selain memperluas kajian sebelumnya, juga dapat digunakan sebagai dasar pengambilan keputusan di bidang saluran pemasaran dan sekaligus mengevaluasi efektivitas strategi pemasaran melalui media online.

\section{KAJIAN PUSTAKA}

Teori pembelajaran sosial oleh Bandura (1963) telah banyak diterapkan dalam penelitian akademik, khususnya dalam bidang komunikasi dan periklanan (Lim et al., 2017). Teori ini bertindak sebagai kerangka kerja teoritis untuk memberikan ide-ide agen sosialisasi yang dapat memprediksi perilaku konsumsi (King \& Multon 1996; Martin \& Bush 2000). Teori pembelajaran sosial membenarkan bahwa seseorang memperoleh motivasi dan akibatnya menunjukkan sikap yang baik dari agen sosialisasi melalui interaksi sosial langsung atau tidak langsung (dalam Lim et al., 2017). Dengan demikian, teori pembelajaran sosial menyatakan bahwa niat individu untuk membeli produk sangat dipengaruhi oleh sikap responden dan efektivitas pengaruh media sosial (yaitu, kredibilitas sumber, daya tarik sumber, daya tarik produk, kecocokan produk dan transfer makna) dalam mempromosikan produk (dalam Lim et al., 2017).

\section{Pemasaran digital dan minat beli}

Kualitas dan kinerja layanan bisnis meningkat dan didorong oleh penggunaan proses inovatif untuk logistik dan otomatisasi layanan. Manajemen, kualitas dan kecepatan transmisi data telah menjadi faktor kunci untuk daya saing di internet. Penggunaan internet semua tahap ekonomi baru, yang, bersama dengan Electronic Commerce, menawarkan cara-cara baru dalam melakukan bisnis seperti teknik Pemasaran baru, salah satunya adalah melalui media sosial. Istilah e-marketing dalam pemasaran digital dan ditandai dengan penggunaan inovasi web dan intuitif untuk menciptakan koneksi antara perusahaan dan kliennya. E-marketing berkonsentrasi pada penggunaan IT yang diberdayakan atau afiliasi interaktif dengan klien mereka. Ahmed et al. (2017) menjelaskan bahwa pemasaran elektronik (EM), atau pemasaran digital adalah pertukaran produk dan layanan melalui perangkat elektronik dan proses dari penjual ke pembeli.

Pemasaran digital telah memberikan arah baru ke pola pemasaran tradisional dengan menyediakan hal yang biasa bagi pelanggan untuk berbagi ide. Pemasaran digital menyediakan fasilitas kepada pemasar dan konsumen berdasarkan lokasi waktu nyata untuk respon yang lebih cepat. Pemasar digital menggunakan fitur interaktif dan digital untuk menyediakan informasi dan memilah pelanggan berdasarkan kebutuhan mereka, melalui saluran media yang sangat baik dan paling efektif untuk menciptakan kesadaran merek (Ahmed et al., 2017).

Simamora (2011:106) menjelaskan bahwa minat beli (niat beli) terhadap suatu produk timbul karena adanya dasar kepercayaan terhadap produk yang diiringi dengan kemampuan untuk membeli produk. Selain itu, niat beli terhadap suatu produk juga dapat terjadi dengan adanya pengaruh dari orang lain yang dipercaya oleh calon konsumen, misal: keluarga atau sahabat. Niat beli juga dapat timbul apabila seornag konsumen merasa sangat tertarik terhadap berbagai informasi seputar produk yang diperoleh melalui iklan, pengalaman orang yang telah menggunakannya, dan kebutuhan yang mendesak terhadap suatu produk. Niat pembelian digambarkan sebagai perilaku transaksi yang ditunjukkan oleh pelanggan setelah melakukan evaluasi barang dan jasa (Schiffman \& Kanuk, 2010). Menurut Alford dan Biswas (2000, dalam Tariq et al., 2017), niat pembelian adalah perilaku kemungkinan konsumen untuk membeli, niat pembelian yang lebih tinggi berarti konsumen memiliki kemungkinan pembelian yang lebih tinggi.

Setiap kali konsumen berniat untuk membeli produk apa pun, mereka menyelidiki lokasi yang

relevan dan mengumpulkan informasi berdasarkan pengalaman dan lingkungan mengenai produk 
atau layanan tersebut setelah mengumpulkan informasi yang cukup konsumen membuat perbandingan dan mengevaluasi produk dan membuat penilaian terhadapnya (Wang, Cheng \& Chu, 2012). Niat pembelian meningkat dengan harga dan promosi (Alford \& Biswas, 2000), dengan pengakuan merek (Dodds, Monroe, \& Grewal, 1991, dalam Tariq et al., 2017), dan juga melalui peningkatan keakraban konsumen dengan merek (Johnson \& Russo, 1984, dalam Tariq et al., 2017)

\section{Hubungan antara pemasaran digital terhadap minat beli}

Seperti yang disebutkan oleh Alalwan et al. (2017), ada beberapa praktik pemasaran berbeda yang dapat diterapkan oleh perusahaan melalui platform media sosial yaitu iklan, e-WOM, manajemen hubungan pelanggan, dan branding). Dalam studinya, Alalwan (2018) mendukung model mengenai dampak yang signifikan dari kinerja media, motivasi hedonis, interaktivitas, informativeness, dan relevansi yang dirasakan pada niat pembelian konsumen. Menggunakan dasar teori pembelajaran sosial, Lim et al. (2017) menemukan bahwa kredibilitas sumber, sumber daya tarik, kecocokan produk, dan transfer makna yang dapat mempengaruhi sikap konsumen dan konsekuensi pembelian. Oleh karena itu, hasil dari penelitian ini memvalidasi temuan efek mediasi dari sikap konsumen antara efektivitas influencer media sosial (yaitu, Transfer Makna, Pencocokan Produk, dan Sumber Daya Tarik) dan niat beli. Sejalan dengan itu, hasil pada penelitian yang dilakukan oleh Ompusunggu (2018) menyimpulkan bahwa Digital Marketing atau Pemasaran Digital berpengaruh terhadap Minat Beli. Pemasaran Digital menjadi faktor yang penting dalam menarik minat beli konsumen di era modern ini, dimana semua informasi bisa didapat dengan cepat melalui social media. Maka dari itu, pemilik toko harus dapat menarik perhatian konsumen melalui Pemasaran Digital. Sehingga dapat disimpulkan hipotesis sebagai berikut:

$\mathrm{H}_{1}$ : Variabel Pemasaran Digital memiliki pengaruh terhadap Minat Beli

\section{Hubungan antara suasana toko terhadap minat beli}

Atmospherics di toko ritel tradisional didefinisikan sebagai "perancangan ruang secara sadar untuk menciptakan efek spesifik pada pembeli" (Kotler, 2012). Aboiron dan Aubin mendefinisikan suasana menurut enam variabel (Rieunier, 2000) dan tiga dimensi dari Lemoine, (2003). Suasana terdiri dari enam variabel. Lima di antaranya adalah fisik yang sesuai dengan panca indera (sentuhan, pendengaran, rasa, bau, dan penglihatan), yang dapat dikelola oleh merek itu sendiri; dan variabel terakhir adalah sosial (kepribadian pegawai toko, tipe pelanggan, interaksi). Atmosfer dan lingkungan toko memiliki makna lebih besar dibandingkan dengan input pemasaran yang tidak ada di titik pembelian (de Farias, Aguiar \& Melo, 2014). Konsep serupa dapat diterapkan pada konteks online juga. Hussain dan Ali (2015) mengemukakan bahwa pedagang online juga membangun suasana melalui situs web mereka. Suasana ini dapat memiliki dampak yang kuat terhadap persepsi pembeli tentang toko online dan pengalaman pembelian mereka. Hausman dan Siekpe (2009) berkonsentrasi pada pilihan bahasa, layanan hadiah, humor, fitur pencarian global dan indikasi keamanan sebagai ukuran atmosfer web. Abrar, Zaman dan Satti (2017) menyimpulkan bahwa vendor online harus mempertimbangkan isyarat yang relevan dengan tugas tinggi dan rendah (Informativeness, Navigasi Situs Web, Hiburan dan Desain Situs Web) saat merancang atmosfer toko online mereka. Elemen-elemen ini ditemukan secara positif mempengaruhi pengalaman konsumen dan niat mereka untuk melakukan pembelian kembali. Tansya, Semuel, dan Adiwijaya, M. (2019) memberikan dukungan pada penelitian tersebut dan menyatakan bahwa store atmosphere mempunyai pengaruh positif dan signifikan terhadap purchase intention. Sehingga dapat disimpulkan dengan hipotesis sebagai berikut:

$\mathrm{H}_{2}$ : Variabel Citra Toko memiliki pengaruh terhadap Minat Beli

\section{METODE}

\section{Desain Penelitian}

Pendekatan kuantitatif dipilih untuk menjelaskan fenomena yang terjadi berdasarkan hipotesis yang diajukan. Data untuk semua variabel dikumpulkan pada titik yang sama dalam waktu yang berarti 
pendekatan yang digunakan adalah cross sectional. Obyek penelitian ini adalah Kedai Kopi S. Sedangkan subyek yang digunakan adalah pengunjung Kedai Kopi S di wilayah Jakarta Pusat. Jenis data pada penelitian ini menggunakan data primer dengan jumlah sampel sebesar 105 responden secara purposive. Adapun kriteria yang digunakan untuk menyeleksi sampel adalah sebagai berikut: (1) pernah mengunjungi Kedai Kopi S, dan (2) pernah mengakses Instagram Kedai Kopi S. Teknik pengumpulan data dilakukan dengan metode survei dengan menyebarkan kuesioner yang berisikan pernyataan-pernyataan yang menyangkut seputar topik penelitian kepada responden yang diukur menggunakan Skala Likert. Responden dalam penelitian ini terdiri dari 56,5\% perempuan dan 43,5\% laki-laki, sebagian besar milenial (90\%) yang usianya antara 21-30 tahun. Dalam hal tingkat pendidikan, 85,5\% responden berpendidikan SMA, 8,0\% dengan pendidikan sarjana, dan 4,50\% tidak bersedia menjawab.

\section{Pengukuran}

Seluruh skala pengukuran diadaptasi dari Abrar et al. (2017) yang memvalidasi Pemasaran digital (3 item: Informativeness, desain situs web, hiburan, Navigasi Situs Web), Suasana Toko (4 item) dan minat beli (3 item). Kuesioner digunakan untuk mengeksplorasi dan mengumpulkan informasi mengenai persepsi konsumen terhadap pernyataan yang diajukan. Dalam kuesioner, peserta diminta untuk menilai tingkat persetujuan mereka dengan item-item tertentu menggunakan skala lima poin tipe Likert, berlabuh dengan sangat tidak setuju dan sangat setuju.

Untuk menentukan kepercayaan instrumen yang digunakan, analisis reliabilitas dilakukan. Nunnally (1994) menjelaskan bahwa ketika nilai Cronbach's Alpha lebih dari 0,7, keandalan data dapat diterima. Berdasarkan hasil analisis diketahui bahwa nilai-nilai Cronbach's Alpha untuk semua variabel independen dan dependen lebih dari 0,7 yang menunjukkan keandalan data yang dikumpulkan untuk penelitian ini. Nilai-nilai tersebut adalah 0,912 (pemasaran digital), 0,769 (suasana toko), dan 0,887 (minat beli). Uji validitas menggunakan analisis faktor. Berdasarkan nilai koefisien bobot faktor diketahui bahwa seluruh item sudah memailiki validitas yang memadai (Loading factor $>0.50$ ).

\section{HASIL DAN PEMBAHASAN}

\section{Analisis deskriptif}

Tabel 1 menunjukkan nilai mean, skewness dan kurtosis. Rata-rata pemasaran digital, suasana toko dan niat beli menunjukkan gambaran dalam populasi, nilai skewness dan kurtosis masing-masing berada di antara - $1 \&+1$ dan $-3 \&+3$, skewness dan kurtosis untuk e emasaran digital, suasana toko dan niat beli berada di antara $-3 \&+3$ yang menunjukkan bahwa data terdistribusi secara normal

Tabel 1. Deskripsi data

\begin{tabular}{|c|c|c|c|c|c|}
\hline Variabel & $\mathbf{N}$ & Mean & St.Dev & Skewness & Kurtosis \\
\hline Pemasaran Digital & 105 & 3.346 & 0.916 & 1.564 & 0.725 \\
\hline Suasana Toko & 105 & 3.826 & 0.963 & 1.812 & 2.360 \\
\hline Niat Beli & 105 & 3.201 & 1.051 & 1.022 & 1.304 \\
\hline
\end{tabular}

Sumber: diolah

\section{Analisis regresi}

Analisis regresi diterapkan untuk memeriksa sejauh mana niat pembelian dipengaruhi oleh semua variabel independen yang dipertimbangkan dalam penelitian ini. Tes regresi linier dilakukan untuk setiap variabel tunggal yang termasuk dalam penelitian ini. Temuan analisis regresi ditunjukkan pada tabel 2 yang menunjukkan bahwa 45.2\% variasi dalam niat pembelian disebabkan oleh digital marketing dan suasana toko. 
Tabel 2. Hasil analisis regresi

\begin{tabular}{lcrrrr}
\hline Variabel & Koefisien & \multicolumn{1}{c}{ SE } & \multicolumn{1}{c}{ t-value } & \multicolumn{1}{l}{ Sig } & \\
\hline Pemasaran Digital & .291 & .093 & 3.140 & .002 \\
Suasana Toko & .549 & .095 & 5.781 & .000 \\
R & .452 & & & \\
F-statistik & 5.732 & & & \\
\hline Sumb:
\end{tabular}

Sumber: diolah

Hasil analisi menunjukkan hubungan positif dan signifikan antara semua variabel independen dan dependen. Nilai t untuk semua variabel lebih dari 2, menggambarkan pengaruh signifikan dari variabel. Nilai $F$ untuk semua variabel lebih dari 4 yang menentukan signifikansi statistik dari model regresi keseluruhan. Tabel-6 mendukung hipotesis yang diajukan bahwa digital marketing dan atmosfer toko memiliki hubungan positif dengan niat pembelian. Statistik yang ditunjukkan pada tabel-1 menunjukkan bahwa semua hipotesis didukung.

\section{Pembahasan}

Tren bisnis global telah mengalami transformasi besar-besaran sejak kedatangan internet. Konsumen saat ini memiliki banyak opsi untuk melakukan pembelian, dengan salah satu opsi paling signifikan adalah belanja online. Belanja online mengacu pada aktivitas pembelian barang atau jasa melalui internet (Kukar-Kinney \& Close, 2010). Ini telah memberi konsumen kemudahan dan kenyamanan untuk mencari, membandingkan, dan memilih produk sambil duduk di rumah atau tempat kerja tanpa mengeluarkan waktu dan biaya yang terkait dengan transaksi fisik. Tren ini telah menyebabkan banyak bisnis menawarkan produk yang sama di toko online mereka juga (Adnan, 2014). Ini tidak hanya membuat kehadiran mereka diketahui tetapi juga memberi mereka keunggulan kompetitif yang kuat atas bisnis tradisional. Dapat dinyatakan bahwa adanya promosi di sosial media dilakukan untuk menarik dan mempertahankan konsumen; Oleh karena itu, penting untuk mempelajari perilaku konsumen dalam konteks online dan mengidentifikasi beberapa variabel penting yang memainkan peran penting dalam menarik dan mempertahankan pembeli online. Studi yang memadai telah dilakukan pada identifikasi faktor-faktor yang mempengaruhi perilaku konsumen online (Poddar, Donthu, \& Wei, 2009).

Hasil penelitian ini telah mengkonfirmasi hubungan statistik dan signifikan dari semua penentu kerangka kerja konseptual yang diusulkan dengan niat pembelian. Penelitian ini merupakan salah satu penelitian yang memiliki kontribusi dalam menjelaskan perilaku konsumen dari perspektif online dan non-online. Kurangnya literatur sebelumnya tentang dampak atmosfer toko online (dengan dimensi unik yang dipertimbangkan untuk penelitian ini) sehingga memperluas kajian penelitian sebelumnya. Pertama, pemasaran digital ditemukan memiliki hubungan yang tidak signifikan niat beli (H1 didukung). Mendung teori pembelajaran sosial, penelitian ini juga mengkonfirmasi temuan Lim et al. (2017) yang memberikan kesimpulan bahwa kredibilitas sumber, sumber daya tarik, kecocokan produk, dan transfer makna yang dapat mempengaruhi sikap konsumen dan konsekuensi pembelian. Pemasaran Digital menjadi faktor yang penting dalam menarik minat beli konsumen di era modern ini, dimana semua informasi bisa didapat dengan cepat melalui social media. Maka dari itu, pemilik toko harus dapat menarik perhatian konsumen melalui Pemasaran Digital.

Internet adalah salah satu pendorong utama meningkatnya kesenjangan antara pasar dan perusahaan dan salah satu tantangan terbesar untuk pemasaran. Pemasaran digital telah mengubah cara perusahaan mengelola dan berkomunikasi dengan pelanggan dan masyarakat mereka di seluruh dunia. Itu menjadi kunci dan instrumen yang diperlukan untuk menghadapi tantangan yang masih 
ada di bidang pemasaran. Pada saat yang sama, keberlanjutan telah berubah menjadi salah satu tantangan terbesar bagi perusahaan sejak awal abad ke-21, khususnya untuk pemasar. Diskusi antara pemasaran dan keberlanjutan telah diperlakukan secara luas oleh para peneliti, menghasilkan fakta bahwa kedua konsep memiliki hal-hal yang saling menguntungkan satu sama lain (Diez-Martin et al., 2019).

Kedua, suasana toko secara positif dan signifikan terhadap minat beli konsumen. Hal ini berarti semakin baik suasana toko, maka semakin tinggi pula niat beli konsumen. Hal ini sejalan dengan temuan Abrar, Zaman dan Satti (2017) menyimpulkan bahwa vendor online harus mempertimbangkan isyarat yang relevan dengan tugas tinggi dan rendah (Informativeness, Navigasi Situs Web, Hiburan dan Desain Situs Web) saat merancang atmosfer toko online mereka. Elemenelemen ini ditemukan secara positif mempengaruhi pengalaman konsumen dan niat mereka untuk melakukan pembelian kembali. Tansya, Semuel, dan Adiwijaya (2019) juga memberikan dukungan pada penelitian tersebut dan menyatakan bahwa store atmosphere mempunyai pengaruh positif dan signifikan terhadap purchase intention. Jika pembeli menikmati waktu mereka di ruangan, ini bisa menjadi argumen utama untuk membenarkan investasi terkait dengan penciptaan dan pengembangan atmosfer toko. Penjual dapat menggunakan suasana yang baik karena akan memberikan pengalaman belanja yang menyenangkan kepada pelanggan dan ingin menciptakan / memperkuat hubungan pelanggan dan memengaruhi merek.

\section{KESIMPULAN}

Tujuan utama untuk penelitian ini adalah untuk menyelidiki hubungan pemasaran digital dan atmosfer toko dengan niat pembelian. Hasilnya menunjukkan hubungan yang positif antara variabel independen dan dependen. Hubungan pemasaran digital dengan niat pembelian menunjukkan bahwa konsumen termotivasi untuk membeli dari situs web yang mereka anggap informatif, mudah dinavigasi, menghibur, dan menarik. Korelasi antara suasana toko dan niat pembelian memberikan kesimpulan bahwa suasana toko baik dari sisi fisik dan non fisik (misalnya sikap pegawai) memberikan efek positif pada niat pembelian.

Dari perspektif implikasi manajerial, penelitian ini menawarkan pemasar beberapa pertimbangan praktis dalam memilih influencer media sosial, yang dirancang untuk iklan untuk mendapatkan keunggulan kompetitif di pasar. Berdasarkan analisis data, pemasaran digital yang dijalankan belum terlalu efektif mempengaruhi minat beli konsumen dibandingkan dengan sauna toko. Kondisi ini perlu diperbaiki oleh perusahaan untuk memperhatikan pemilihan influencer media sosial yang tepat untuk meningkatkan sikap konsumen serta mempengaruhi niat beli. Suasana toko sangat membantu menentukan citra toko dan dapat memikat hati konsumen dan membuat konsumen nyaman berada di toko tersebut. Suasana toko mempengaruhi keadaan emosional pembeli yang akan merasa senang dan nyaman. Berbagai keputusan dalam penentuan desain luar dan dalam suatu toko akan menciptakan suatu lingkungan toko yang menyenangkan untuk sebuah kafe. Banyak konsumen yang menilai suatu toko hanya berdasarkan penampilan luarnya untuk lalu memutuskan si konsumen tersebut akan masuk atau tidak ke dalam toko berdasarkan persespi yang dibuatnya.

\section{Keterbatasan}

Dalam studi ini, data yang digunakan masih terbayas sehingga riset berikutnya perlu mengembangkan ukuran sampel yang lebih besar untuk mengeksplorasi topik ini dan pada akhirnya menghasilkan hasil yang sangat luas. Latar belakang responden juga merupakan faktor pembatas, karena mereka didominasi remaja dengan pendapatan minimal. Karena itu, mereka mungkin bukan prediktor daya beli yang baik. Studi di masa depan harus diperluas ke rentang konsumen milenium yang lebih luas. 


\section{REFERENSI}

Aboiron, J., \& Aubin, J. (2016). Influence of Store Atmosphere on the Shopper's Behavior: The Case of Yves Rocher. Journal of Business and Economics, 2058.

Abrar, K., Zaman, S., \& Satti, Z. W. (2017). Impact of Online Store Atmosphere, Customized Information and Customer Satisfaction on Online Repurchase Intention. Global Management Journal for Academic \& Corporate Studies, 7(2), 22-34.

Adnan, H. (2014). An analysis of the factors affecting online purchasing behavior of Pakistani consumers. International Journal of Marketing Studies,6(5), 133-148

Ahmed, R. R., Vveinhardt, J., \& Streimikiene, D. (2017). Interactive digital media and impact of customer attitude and technology on brand awareness: evidence from the South Asian countries. Journal of Business Economics and Management, 18(6), 1115-1134.

Ahuja, V. 2015. Development of an optimal solution for digital marketing variables in an online tool, International Journal of Internet Marketing and Advertising 9(1): 49.

Alalwan, A. A. (2018). Investigating the impact of social media advertising features on customer purchase intention. International Journal of Information Management, 42, 65-77.

de Farias, S. A., Aguiar, E. C., \& Melo, F. V. S. (2014). Store atmospherics and experiential marketing: A conceptual framework and research propositions for an extraordinary customer experience.International Business Research,7(2), 87-99

Diez-Martin, F., Blanco-Gonzalez, A., \& Prado-Roman, C. (2019). Research Challenges in Digital Marketing: Sustainability. Sustainability, 11(10), 2839.

Hausman, A. V., \& Siekpe, J. S. (2009). The effect of web interface features on consumer online purchase intentions.Journal of Business Research, 62(1), 5-13

Hussain, R., \& Ali, M. (2015). Effect of Store Atmosphere on Consumer Purchase Intention.International Journal of Marketing Studies,7(2), 35-43

Jayaram, D., Manrai, A. K., \& Manrai, L. A. (2015). Effective use of marketing technology in Eastern Europe: Web analytics, social media, customer analytics, digital campaigns and mobile applications. Journal of Economics, Finance and Administrative Science, 20(39), 118-132.

Joshi, S. (2013, July). A study on digital marketing preferences of generation Y with specific reference to the purchase of laptops. In PRIMA (Vol. 4, No. 1). Publishing India Group.

Järvinen, J., \& Karjaluoto, H. (2015). The use of Web analytics for digital marketing performance measurement. Industrial Marketing Management, 50, 117-127.

Karjaluoto, H., Ulkuniemi, P., \& Mustonen, N. (2015). The role of digital channels in industrial marketing communications. Journal of Business \& Industrial Marketing.

Khan, A., \& Islam, M. (2017). The Impact of Digital Marketing on increasing Customer Loyalty: A Study on Dhaka City, Bangladesh. International Journal of Economics, Commerce and Management, 5(4).

Kukar-Kinney, M., \& Close, A. G. (2010). The determinants of consumers' online shopping cart abandonment. Journal of the Academy of Marketing Science,38(2), 240-25

Kotler, Philip (2012). Manajemen Pemasaran, Edisi 13. Jakarta: Erlangga

López-García, D. A., Torreglosa, J. P., \& Vera, D. (2019). A decentralized P2P control scheme for trading accurate energy fragments in the power grid. International Journal of Electrical Power \& Energy Systems, 110, 271-282.

Lim, X. J., Radzol, A. M., Cheah, J. H., \& Wong, M. W. (2017). The impact of social media influencers on purchase intention and the mediation effect of customer attitude. Asian Journal of Business Research, 7(2), 19-36.

Okazaki, S., Katsukura, A., \& Nishiyama, M. (2007). How mobile advertising works: The role of trust in improving attitudes and recall. Journal of advertising research, 47(2), 165-178.

Pauwels, K., Aksehirli, Z., \& Lackman, A. (2016). Like the ad or the brand? Marketing stimulates different electronic word-of-mouth content to drive online and offline performance. International Journal of Research in Marketing, 33(3), 639-655.

Poddar, A., Donthu, N., \& Wei, Y. (2009). Web site customer orientations, Web site quality, and purchase intentions: The role of Web site personality. Journal of Business Research,62(4), 441450.

Siddhibphongsa, P., \& Kim, S. (2017). The influences of store atmosphere on purchase intention toward a fast fashion brand in Bangkok. AU-GSB e-JOURNAL, 9(1), 124. 
Jurnal Manajemen Strategi dan Aplikasi Bisnis, 3(1), 21-30

Albi, K. Pemasaran Digital, Suasana Toko, Minat Beli

Sinha, M., \& Fukey, L. (2019). Impact Of Digital Marketing And Customer Purchase Intention With Respect To Jewellery Industry. International Journal Of Management And Social Sciences (IJMSS), 8(2.6), 10-18.

Schiffman, L. G., \& Kanuk, L. L. (2010). Consumer Behavior. New Jersey: Pearson-Prentice Hall.

Tansya, S., Semuel, H., \& Adiwijaya, M. (2019). Pengaruh Store Atmosphere terhadap Store Image dan Purchase Intention Produk Fashion Merek Zara di Surabaya. Petra Business and Management Review, 5(1).

Tariq, M., Abbas, T., Abrar, M., \& Iqbal, A. (2017). EWOM and brand awareness impact on consumer purchase intention: Mediating role of brand image. Pakistan Administrative Review, 1(1), 84102.

Wang, J., Cheng, Y., \& Chu, Y. (2012). Product familiarity and learning new information. Journal of Consumer Research, 11(1),542-550

\section{PROFIL PENULIS}

Khalifachri Albi adalah dosen manajemen di STIE ISM. Bidang kajian utama adalah pemasaran dan perilaku konsumen. Penulis dapat dihubungi di emal: khalifachrialbi@gmail.com 
Jurnal Manajemen Strategi dan Aplikasi Bisnis, 3(1) , 21-30 Albi, K. Pemasaran Digital, Suasana Toko, Minat Beli

This page intention to blank. 